\title{
PENGARUH KOMPENSASI TERHADAP KINERJA KARYAWAN PADA PT. TRIGUNUNG PADUTAMA DI BANDAR LAMPUNG
}

\author{
Yuchi Tomas $^{(1)}$, Husna Purnama ${ }^{(2)}$, Khairul Saleh ${ }^{(3)}$ \\ Fakultas Ekonomi Universitas Sang Bumi Ruwa Jurai \\ yuchi.tomas11@gmail.com,husna.purnama@fe.saburai.ac.id, khairul.saleh@fe.saburai.ac.id
}

\begin{abstract}
Abstrak. Pemberian kompensasi sangat penting artinya bagi karyawan karena dapat menjadi pendorong semangat kerja karyawan. Selain itu, besar kecilnya kompensasi secara tidak langsung akan menjadi tolok ukur kinerja karyawan. Identifikasi masalah dalam penelitian ini adalah kompensasi belum memadai serta pembagiannya seringkali terlambat, serta penyelesaian pekerjaan yang tidak tepat waktu, pelayanan kurang efektif atau terkesan lambat merupakan cerminan dari rendahnya kinerja karyawan. Tujuan penelitian untuk mengetahui pengaruh kompensasi terhadap kinerja karyawan. Objek penelitian ini adalah seluruh karyawan pada PT. Trigunung Padutama yang berjumlah 92 orang karyawan. Pengujian Hipotesis menggunakan uji T untuk mengetahui pengaruh variabel independen secara parsial terhadap variabel dependen. Uji Hipotesis

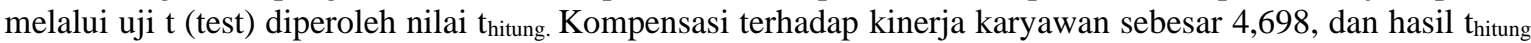
$=4,698>\mathrm{t}_{\text {tabel }}=1,661$. Hasil ini menunjukkan bahwa terdapat pengaruh kompensasi terhadap kinerja karyawan pada PT. Trigunung Padutama. Hasil uji koefisien determinasi (KD), sebesar 67,8\% ini berarti kompensasi mempunya pengaruh terhadap kinerja karyawan sebesar $67,8 \%$ dan sisanya sebesar $32,2 \%$ dipengaruhi faktor lain.
\end{abstract}

Kata kunci: Karyawan, Kinerja, Kompensasi, Pengaruh.

\section{PENDAHULUAN}

Era globalisasi telah melanda berbagai aspek kehidupan manusia. Dalam bidang perekonomian hal ini membawa dampak yang cukup besar bagi industri- industri di Indonesia baik itu industri perdagangan, manufaktur maupun jasa. Oleh karena itu, dengan pengaruh lingkungan bisnis yang begitu kuat, mendorong perusahaan untuk melakukan pembenahan diri agar dapat bersaing dan mempertahakan hidup. Untuk melakukan hal tersebut, perlu adanya suatu rancangan strategik.

Namun perbaikan dalam satu aspek tersebut masih dirasa kurang cukup tanpa disertai dengan perbaikan dalam aspek kualitas sumber daya manusia dalam perusahaan yaitu kualitas karyawan itu sendiri, hal itu dikarenakan peran karyawan yang sangat besar dalam keberhasilan tercapainya tujuan perusahaan. Untuk itu, dunia kerja saat ini menuntut kita untuk menjadi seorang manusia dengan sumber daya yang kompeten.

Keberadaan sumber daya manusia di dalam suatu perusahaan memiliki peranan penting, baik itu perusahaan milik pemerintah maupun swasta, hal itu dikarenakan tenaga kerja memiliki potensi yang besar untuk menjalankan aktivitas perusahaan. Potensi setiap sumber daya manusia yang ada dalam perusahaan harus dapat dimanfaatkan dengan sebaik- baiknya sehingga mampu memberikan kinerja yang optimal.

Untuk dapat melaksanakan tugas dan fungsinya dengan sebaik mungkin maka dibutuhkan kinerja yang baik sehingga tercipta hasil kerja yang baik bagi perusahaan. Salah satu dorongan seseorang untuk meningkatkan kinerjanya pada suatu organisasi adalah adanya kompensasi, sudah menjadi sifat dasar dari manusia pada umumnya untuk menjadi lebih baik, lebih 
maju dari posisi yang dipunyai pada saat ini.

Pemberian kompensasi sangat penting artinya bagi karyawan karena dapat menjadi pendorong semangat kerja karyawan. Selain itu, besar kecilnya kompensasi secara tidak langsung akan menjadi tolok ukur kinerja karyawan. Sehingga apabila sistem kompensasi yang diberlakukan oleh organisasi cukup adil terhadap karyawan akan menjadikan stimulan bagi karyawan dalam bekerja dengan lebih baik serta lebih bertanggung jawab terhadap tugas-tugas yang diberikan organisasi (Prawirosentono, 2009).

Dalam perkembangannya, kompensasi tidak hanya diperhatikan oleh organisasi swasta, melainkan organisasi pemerintah juga dalam meningkatkan kinerja karyawan.Pemberian kompensasi yang tepat merupakan salah satu cara yang dapat digunakan perusahaan untuk meningkatkan motivasi dan komitmen karyawan untuk mencapai kinerja yang diinginkan perusahaan, karena dengan adanya kompensasi akan menciptakan keselarasan tujuan antara karyawan yang menginginkan upah yang lebih dengan perusahaan yang menginginkan kinerja yang lebih dari para karyawannya.

Dalam era globalisasi ini banyak perusahaanperusahaan yang kerap menawarkan sistem insentif baik berupa bonus maupun tunjangan lainnya, baik itu merupakan perusahaan pemerintah maupun milik swasta. Mereka seringkali memberikan insentif yang berbeda bagi setiap karyawan yang dianggap kompeten di bidangnya, sehingga pihak perusahaan menyadari bahwa pemberian insentif kepada karyawan merupakan hal yang sangat penting.

Kinerja merupakan hasil dan prilaku kerja yang dihasilkan oleh seorang karyawan sesuai dengan perannya dalam organisasi dalam suatu periode tertentu. Kinerja karyawan yang baik adalah salah satu faktor yang sangat penting dalam upaya untuk meningkatan produktivitas. Oleh karena, itu salah satu cara terbaik untuk meningkatkan kinerja karyawan adalah dengan memberikan kompensasi kepada karyawan agar dapat memotivasi sehingga karyawan lebih meningkatkan lagi kinerjanya, sehingga kinerjanya meningkat dan perusahaan pun mampu menghasilkan produk dengan harga yang kompetitif.

Untuk menopang pelaksanaanpelaksanaan tugas-tugas tersebut sangat dibutuhkan sumber daya manusia yang memiliki kinerja/prestasi kerja tinggi agar dapat menghasilkan pelayanan berkualitas, karena kualitas kerja organisasi sangat bergantung pada prestasi kerja individuindividu didalamnya.

Faktor-faktor yang mempengaruhi kesejahteraan karyawan dalam rangka peningkatan kinerjanya adalah faktor yang berhubungan dengan jaminan serta kesejahteraan karyawan yang meliputi sistem dan besarnya gaji, jaminan sosial, macam-macam tunjangan, lingkungan kerja, fasilitas yang diberikan, promosi, dan sebagainya.

Kinerja karyawan erat kaitannya dengan penilaian kinerja, untuk itu penilaian kinerja karyawan perlu dilakukan oleh suatu organisasi. Penilaian kinerja (performance evaluation) yaitu proses untuk mengukur atau mengevaluasi hasil pekerjaan yang dilakukan seseorang atau sekelompok orang dalam organisasi (Rivai, 2005). Dengan kata lain penilaian kinerja ditentukan oleh hasil kegiatan sumber daya manusia (SDM) dengan standar kinerja yang telah ditetapkan organisasi sebelumnya.

Kompensasi merupakan hal yang kompleks dan sulit, karena di dalamnya melibatkan dasar kelayakan, logika, rasional, dan dapat dipertanggung jawabkan serta mengangkut faktor emosional dari aspek tenaga kerja. Kompensasi diberikan dengan tujuan memberikan rangsangan dan 
motivasi kepada tenaga kerja untuk meningkatkan kinerja, serta efesiensi dan efektivitas produksi.

Berdasarkan uraian tersebut maka peneliti tertarik untuk melakukan penelitian mengenai "Pengaruh Kompensasi terhadap Kinerja PT. Trigunung Padutama di Bandar Lampung ."

\section{KAJIAN TEORI}

\section{Pengertian Kompensasi}

Kompensasi adalah fungsi manajemen sumber daya manusia yang berkaitan dengan semua bentuk penghargaan yang dijanjikan akan diterima karyawan sebagai imbalan dari pelaksanaan tugas dalam upaya pencapaian tujuan perusahaan (Ivancevich, 2004).

Kompensasi kerja adalah segala sesuatu yang diterima oleh karyawan sebagai balas jasa untuk kerja mereka (Tohardi, 2012). Kompensasi kerja merujuk pada semua bentuk upah atau imbalan yang berlaku bagi dan muncul dari pekerjaan mereka, dan langsung dalam bentuk upah, gaji, insentif, komisi, dan bonus, dan ada pembayaran tidak langsung dalam bentuk tunjangan keuangan seperti asuransi dan uang liburan.

Dari pengertian di atas dapat diketahui ciri-ciri imbalan atau kompensasi, yaitu (Tohardi, 2012):

1. Kompensasi merujuk kepada semua bentuk imbalan keuangan.

2. Kompensasi diperoleh dari pelayanan yang nyata dan manfaat yang diterima karyawan sebagai bagian dari suatu hubungan pekerjaan.

3. Kompensasi merupakan penghargaan finansial yang diberikan kepada karyawan.
Berdasarkan pengertian-pengertian tersebut diatas dapat disimpulkan bahwa kompensasi atau imbalan merupakan semua bentuk pembayaran yang diberikan oleh organisasi/perusahaan kepada karyawan sebagai balas jasa atas pelaksanaan tugas atau kontribusi karyawan kepada organisasi, baik yang diberikan secara teratur maupun situasional.

\section{Faktor-Faktor dalam Menentukan Pemberian Imbalan}

Handoko (2000) menyatakan kompensasi adalah segala sesuatu yang diterima para karyawan sebagai balas jasa untuk kerja mereka, penentuan besarnya kompensasi dipengaruhi oleh beberapa tantangan, antara lain :

1. Suplai dan permintaan tenaga kerja

Beberapa jenis pekerjaan mungkin harus dibayar lebih tinggi daripada yang ditunjukan oleh nilai relatifnya karena desakan kondisi pasar. Sebagai contoh pada tahun 1970-an, kelangkaan tenaga akuntan menyebabkan perusahaan (organisasi) harus memberikan tunjangan kelangkaan di samping kompensasi dasar untuk memperoleh tenaga kerja akuntan.

2. Serikat karyawan/karyawan

Lemah atau kuatnya serikat karyawan/karyawan mencerminkan kemampuan organisasi tersebut untuk menggunakan kekuatan pengaruh mereka pada penentuan tingkat kompensasi. Semakin kuat kekuatan serikat berarti semakin kuat posisi perundingan karyawan/karyawan dalam penetapan tingkat upah mereka.

3. Produktivitas

Perusahaan harus memperoleh laba untuk menjaga kelangsungan hidup dan tumbuh. Tanpa hal ini, perusahaan tidak dapat membayar para 
karyawannya melebihi kontribusi mereka kepada perusahaan melalui produktivitas mereka.

4. Kemampuan untuk membayar Perusahaan juga merasa bahwa para karyawan/karyawan seharusnya melakukan pekerjaan sesuai dengan upah yang mereka terima. Manajemen perlu mendorong para karyawan/karyawan untuk meningkatkan produksivitas mereka agar kompensasi yang lebih tinggi dapat dibayarkan.

\section{Tujuan Pemberian Imbalan}

Menurut Handoko (2000), tujuan pemberian imbalan atau kompensasi adalah untuk :

1. Memperoleh personalia yang berkualitas

Kompensasi perlu ditetapkan cukup tinggi untuk dapat bersaing dalam pasar tenaga kerja, tingkat pengupahan harus sesuai dengan kondisi suplai dan permintaan tenaga kerja.

2. Mempertahankan para karyawan yang ada

Bila tingkat kompensasi tidak kompetitif, niscaya banyak karyawan yang baik akan keluar. Untuk mencegah perputaran karyawan, pengupahan harus dijaga agar tetap kompetitif dengan perusahaanperusahaan lain.

3. Menjamin keadilan

Administrasi pengupahan dan penggajian berusaha utnuk memenuhi prinsip keadilan. Keadilan atau konsisten internal dan eksternal sangat penting diperhatikan dalam penentuan tingkat kompensasi.

4. Menghargai perilaku yang diinginkan
Kompensasi hendaknya mendorong perilaku-perilaku yang diinginkan. Prestasi kerja yang baik, pengalaman, kesetiaan, tanggung jawab baru dan perilaku-perilaku lain dapat dihargai melalui rencana kompensasi yang efektif.

5. Mengendalikan biaya-biaya

Suatu program kompensasi yang rasional membantu organisasi untuk mendapatkan dan mempertahankan sumber daya manusianya pada tingkat biaya yang layak.

6. Memenuhi peraturan-peraturan legal Seperti aspek-aspek manajemen kekaryawanan lainnya, administrasi kompensasi menghadapi batasanbatasan legal. Program kompensasi yang baik memperhatikan kendalakendala tersebut dan memenuhi semua peraturan pemerintahan yang mengatur kompensasi karyawan.

\section{Faktor-Faktor Yang Mempengaruhi Kinerja}

Pengertian Kinerja Menurut Simamora (2009) adalah proses yang dipakai oleh organisasi untuk mengevaluasi pelaksanaan kerja individu karyawan. Menurut Simamora (2009) faktor-faktor yang mempengaruhi kinerja individu tenaga kerja, yaitu:

1. Loyalitas

Setiap karyawan yang memiliki tingkat loyal yang tinggi pada organisasi, mereka akan diberikan posisi yang baik, hal ini dapat dilihat melalui tingkatabsensi ataupun kinerja yang mereka miliki.

2. Semangat kerja

Organisasi harus menciptakan suasana dan lingkungan kerja yang kondusif hal ini akan meningkatkan semangat kerja 
karyawan dalam menjalankan tugasdi suatu organisasi.

3. Tanggung jawab

Tanggung jawab ini harus dimiliki oleh setiap karyawan baik ia berada pada level jabatan yang tinggi atau pada level yang rendah.

4. Kerjasama

Organisasi perlu membina dan menanamkan hubungan kekeluargaan antar karyawan sehingga memungkinkan karyawan untuk bekerjasama dalam lingkungan organisasi.

5. Prakarsa

Prakarsa ini perlu dibina dan dimiliki baik itu dalam diri karyawan ataupun dalam lingkungan organisasi.

6. Pencapaian target

Dalam pencapaian target biasanya organisasi mempunyai strategi-strategi.

\section{METODE PENELITIAN}

\section{Objek Penelitian}

Objek yang akan diadakan penelitian adalah PT. Trigunung Padutama di Bandar Lampung yang terletak di Jalan Ir. Sutami No. 78 Km. 12 Tanjungkarang Timur di Bandar Lampung. Dan Penelitian di laksanakan pada bulan Juli 2016.

\section{Metode dan Teknik Pengumpulan Data}

Metode atau cara pengumpulan data dalam penelitian ini, adalah merupakan peninjauan langsung pada objek penelitian (field research).

Metode atau cara pengumpulan data dalam penelitian ini, dilakukan dengan cara-cara sebagai berikut :
1. Observasi

Pengumpulan data dengan mengadakan pengamatan dan penelitian secara langsung keadaan perusahaan dengan segala aspek kegiatan yang berhubungan dengan penelitian.

2. Wawancara

Wawancara langsung dengan bagian yang menangani masalah yang diperlukan dalam membahas permasalahan yang terjadi.

3. Dokumentasi

Penyusunan hasil wawancara yang telah dilakukan untuk selanjutnya dilakukan pengolahan data.

4. Kuesioner

Kuesioner, yaitu teknik pengumpulan data yang dilakukan dengan cara memberikan sejumlah pertanyaan tertulis secara terstruktur kepada responden penelitian berkaitan dengan tanggapannya terhadap berbagai variabel yang diteliti dalam penelitian ini.

\section{Sampel dan Populasi}

Menurut Kartini Kartono (2009), yang dimaksud dengan populasi pada penelitian ilmiah adalah, merupakan semua jumlah individu dari mana diambil sampel. Sedangkan menurut HadiSutrisno (2009), bahwa yang dimaksud dengan populasi adalah keseluruhan responden yang menjadi objek penelitian. Berdasarkan pendapat yang menjadi populasi dalam penelitian ini adalah, semua yang menjadi karyawan PT. Trigunung Padutama yang berjumlah 92 karyawan.

\section{Metode Analisis Data}

Analisis kuantitatif yang dilakukan berdasarkan data primer yang diperoleh dari 
penyebaran instrument (daftar pertanyaan) kepada sampel, dan untuk mengetahui pengaruh dari variabel bebas (independent variable) terhadap variabel terikat (dependent variable).

Persamaan Regresi Linear Sederhana menentukan persamaan regresi linear sederhana untuk X :

$$
Y=a+b X+e
$$

Keterangan:

$$
\begin{aligned}
& \mathrm{Y}=\text { Kinerja karyawan } \\
& \mathrm{a}=\text { Konstanta } \\
& \mathrm{b}=\text { Koefisien regresi } \mathrm{X} \\
& \mathrm{X}=\text { Kompensasi } \\
& \mathrm{e}=\text { Faktor kesalahan }
\end{aligned}
$$

Rumus Koefisien Determinasi atau Koefisien Penentu (KP):

$$
K P=(r)^{2} x 100 \%
$$

Untuk menguji secara hipotesis secara parsial digunakan Uji t dengan rumus :

$$
t_{\text {hitung }}=\frac{r \sqrt{N-2}}{\sqrt{1-r^{2}}}
$$

Keterangan:

$$
\begin{array}{ll}
\mathrm{t}_{\text {hitung }} & =\text { Nilai } \mathrm{t} \\
\mathrm{r} & =\text { Koefisien Korelasi } \\
\mathrm{N} & =\text { Jumlah responden }
\end{array}
$$

Kriteria untuk Uji $\mathrm{t}$ adalah sebagai berikut :

a) Jika $t_{\text {hitung }}>t_{\text {tabel }}$ maka Ha diterima dan Ho ditolak.

b) Jika $t_{\text {hitung }} \leq t_{\text {tabel }}$ maka Ha ditolak dan Ho diterima.

\section{HASIL DAN PEMBAHASAN}

Dalam menganalisis pengaruh kompensasi terhadap kinerja karyawan digunakan dua variabel yaitu $\mathrm{X}$ dan $\mathrm{Y}$, dimana variabel $\mathrm{X}$ menyatakan kompensasi, sedangkan Y menyatakan kinerja karyawan Berdasarkan hasil perhitungan tingkat korelasi antar variabel diperoleh besarnya tingkat korelasi antara variabel Kompensasi (X) dengan variabel kinerja karyawan (Y) pada PT. Trigunung Padutama adalah sebesar 0,823. Jika dikonsultasikan dengan tabel Interpretasi Koefesien Korelasi maka tingkat korelasi Kompensasi (X) dengan variabel Kinerja Karyawan (Y) pada PT. Trigunung Padutama dalam kategori korelasi "Sangat Kuat", yakni terletak pada (0,800-1,000).

Berdasarkan hasil penelitian di atas, maka diperoleh Koefisien Determinasi Kompensasi terhadap Kinerja karyawan adalah Koefisien Determinasi $(\mathrm{KD})=\mathrm{R} 2=$ $0,823=0,678 \times 100 \%=67,8 \%$. Dapat disimpulkan bahwa variabel Kompensasi (X) menjelaskan variasi perubahan terhadap variabel Kinerja Karyawan (Y) pada PT. Trigunung Padutama sebesar 67,8\%, sedangkan sisanya dijelaskan oleh faktor lain yang tidak dikaji dalam penelitian ini.

Berdasarkan hasil penelitian maka diperoleh data pengaruh Kompensasi terhadap kinerja karyawan adalah hasil Uji t didapat nilai $\mathrm{t}$ hitung $=13,765$. Apabila dibandingkandengan $\mathrm{t}$ tabel pada taraf signifikan yaitu 1,661, maka thitung = 13,765> ttabel $=1,661$, sehingga dapat disimpulkan bahwa ; Ha yang menyatakan terdapat pengaruh variabel Kompensasi (X) terhadap variabel Kinerja Karyawan (Y) pada PT. Trigunung Padutama dapat diterima. Jadi variabel Kompensasi (X) berpengaruh terhadap variabel Kinerja Karyawan (Y).

Persamaan regresi antara variabel Kompensasi (X) terhadap variabel kinerja karyawan (Y) Pada PT. Trigunung Padutama adalah $\mathrm{Y}=13,423+0,794 \mathrm{X}$, yang artinya setiap kenaikan $1 \%$ daripada variabel Kompensasi akan diikuti oleh naiknya variabel Kinerja Karyawan sebesar 0,794\%. Dan jika kompensasi tidak ada maka kinerja akan tetap sebesar 13,423\%. 


\section{KESIMPULAN DAN SARAN}

\section{Kesimpulan}

Berdasarkan hasil penelitian yang telah dilakukan dapat disimpulkan bahwa kompensasi mempunyai pengaruh terhadap kinerja karyawan pada PT. Trigunung Padutama. Hal tersebut dapat dibuktikan dengan hasil perhitungan regresi linear sederhana, yaitu didapatkan t hitung sebesar 4,698 dengan $t$ tabel 1,661 dengan tingkat keyakinan 95\%. Berdasarkan analisis kuantitatif diperoleh persamaan $\mathrm{Y}=13,423$ $+0,794 \mathrm{X}$. Untuk mengetahui besarnya pengaruh kompensasi terhadap kinerja karyawan digunakan koefisien determinasi (KD), yaitu didapat $67,8 \%$ ini berarti kompensasi mempunya pengaruh terhadap kinerja karyawan sebesar 67,8\%. Dari berbagai indikasi yang ada secara umum dapat dikatakan bahwa kompensasi mempunyai pengaruh positif terhadap kinerja karyawan di PT. Trigunung Padutama.

\section{Saran}

Adapun saran yang akan diberikan adalah sebagai berikut :

1. Pemberian kompensasi berupa gaji, insentif, tunjangan kesempatan, program perlindungan, dan tunjangan fasilitas terhadap karyawan perlu ditingkatkan sehingga dapat memotivasi karyawan dalam meningkatkan kinerja.

2. Perlu dibenahi adalah peningkatan kuantitas dan kualitas hasil pekerjaan, menyelesaikan pekerjaan sesuai dengan target waktu yang ditentukan, peningkatan persentase absensi kehadiran datang dan pulang kerja serta kehadiran pada apel pagi, dan kerjasama antar karyawan dalam rangka untuk memudahkan penyelesaian suatu pekerjaan. Dengan demikian diharapkan kinerja karyawan PT. Trigunung Padutama akan menjadi lebih baik lagi.

\section{DAFTAR PUSTAKA}

Arikunto, Suharsimi. 2010. Prosedur Penelitian Suatu Pendekatan dan Praktek, edisi Revisi VII. Jakarta: Rineka Cipta.

Carell, Et.all. 2012. Human Resource Management: Global Strategies for Managing a Diverse Workplace, $5^{\text {th }}$ Edition. New Jersey: Prentice Hall Inc.

Dessler, Garry. 2012. Manajemen Sumber Daya Manusia. New Jersey: Printice Hall Inc.

Gibson, James L., et.al. 2009. Organisasi dan Manajemen, Perilaku, Struktur, Proses, Terjemahan: Djoerban Wahid. Jakarta: Erlangga.

Gomez, R., Luis. Et. All. 2010. Manajemen Sumber Daya Manusia. Yogyakarta: Andi Offset.

Guritno, Bambang dan Waridin. 2005. Pengaruh Persepsi Karyawan Mengenai Perilaku Kepemimpinan, Kepuasan Kerja, dan Motivasi Terhadap Kinerja. JRBI. Vol.01. No.01. Pp 63-74.

Hakim, A. 2009. Analisis pengaruh motivasi, komitmen organisasi dan iklim organisasi terhadap kinerja pegawai pada dinas perhubungan dan telekomunikasi Provinsi Jawa Tengah. Jurnalriset dan bisnis Indononesia. Vol.03. No.02. Pp 165-180. 
Handoko, T. Hani. 2010. Manajemen Personalia Dan Sumber Daya Manusia. Yogyakarta: BPFE.

Ivancevich, JM. 2004. Human Resource Management. New York: McGraw Hill.

Mangkunegara, Anwar Prabu. 2009. Manajemen Sumber Daya Manusia Perusahaan. Bandung: PT. Remaja Rosdakarya.

Masrukhin dan Waridin. 2010. Pengaruh Motivasi Kerja, Kepuasan Kerja, Budaya Organisasi Dan Kepemimpinan Terhadap Kinerja Pegawai. EKOBIS. Vol.07. No.02. Pp 197-209.

Rivai, Veithzal dan Basri. 2010. Performance Appraisal: Sistem Yang Tepat Untuk Menilai Kinerja Karyawan Dan Meningkatkan Daya Saing Perusahaan. Jakarta: PT. Rajagrafindo Persada.

Sugiyono. 2009. Statistik Untuk Penelitian. Bandung: Alfabeta.

Tika, P. 2009. Budaya Organisasi Dan Peningkatan Kinerja Perusahaan. Jakarta: Bumi Aksara.

Wirawan. 2009. Evaluasi Kinerja Sumber Daya Manusia Teori Aplikasi dan Penelitian. Jakarta: Salemba Empat.

Yuwalliatin, Sitty. 2009. Pengaruh Budaya Organisasi, Motivasi Dan Komitmen Terhadap Kinerja Serta Pengaruhnya Terhadap Keunggulan Kompetitif Dosen UNISULA Semarang. EKOBIS. Vol.07. No.02. Pp 241-256. 